\title{
Радіонуклідна діагностика гемодинамічних порушень у чоловіків із цүкровим діабетом 2-го типу
}

\section{Г.А. Зубкова, \\ В.Є. Лучицький}

ДУ «Інститут ендокринології та обміну речовин ім. В.П. Комісаренка НАМН України»

\begin{abstract}
Резюме. Серцево-судинні захворювання $\epsilon$ найбільш поширеною у світі патологією та призводять до інвалідизації та ранньої смерті. 3 їх розвитком тісно пов'язано цукровий діабет 2-го типу (ЦД2), поширеність якого наразі досягла масштабів пандемії. Рання діагностика судинних уражень різних органів і систем у чоловіків із ЦД2 дає можливість за умов вчасного та адекватного лікування запобігти або сповільнити розвиток серцевосудинних подій: інфарктів та інсультів. Мета - дослідження стану тестикулярного, ниркового та мозкового кровобігу в чоловіків, хворих на ЦД2, із використанням радіонуклідного методу. Матеріали та методи. Обстежено 80 чоловіків, хворих на ЦД2, віком від 30 до 65 років. Дослідження стану кровобігу в нижніх кінцівках, нирках, мозковій тканині та яєчках виконували на сцинтиляційній томографічній гамма-камері ГКС-301Т (СКТБ «Оризон»). Результати. В обстежених спостерігали однотипні зміни в обох яєчках у вигляді сповільнення кровобігу в судинах великого, середнього та дрібного калібру, а також збільшення часу повного яєчкового кровобігу. На ранніх стадіях нефропатії у хворих на ЦД2 чоловіків уповільнюється кровобіг у капілярах. У хворих на ЦД2 виявлено вірогідне збільшення часу мозкового кровобігу. Висновок. У пацієнтів із ЦД2 мікроангіопатія передує розвитку макроангіопатії та діагностується радіонуклідними методами ще перед появою клінічної симптоматики.
\end{abstract}

Ключові слова: радіонуклідна ангіографія, цукровий діабет 2-го типу, кровобіг, яєчки.

Цукровий діабет 2-го типу (ЦД2) тісно пов’язано із серцево-судинними захворюваннями [1, 2]. Характерними для ЦД2 є ураження дрібних судин - мікроангіопатії, які $€$ патогенетичними чинниками хронічних

* Адреса для листування (Correspondence): ДУ «Інститут ендокринології та обміну речовин ім. В.П. Комісаренка НАМН України», вул. Вишгородська, 69, м. Київ, 04114, Україна. E-mail: zdovado@ukr.net

() Г.А. Зубкова, В.є. Лучицький ускладнень. Ранні стадії ангіопатій не завжди діагностуються в ході клінічного та лабораторного обстеження хворих, натомість лише за умов ранньої діагностики та вчасного початку лікування можливо сповільнення їх прогресування [3].

Останніми роками дедалі ширше застосовуються інструментальні та радіологічні 
методи (УЗД, МРТ, КТ) для діагностики та контролю ефективності лікування судинної патології різних органів і систем [4]. Водночас методи радіонуклідної діагностики кровобігу досі є недооціненими та маловживаними, хоча відомо, що використання в клінічній практиці сцинтиляційних гамма-камер із комп'ютерною обробкою даних дозволяє значно розширити можливості виявлення ранніх, передклінічних стадій ангіопатій, а також об'єктивно оцінювати ефективність лікування судинних уражень нижніх кінцівок, нирок, печінки, мозоку та іншіх органів у хворих із різною патологією [5].

Мета - дослідження стану тестикулярного, ниркового та мозкового кровобігу в чоловіків, хворих на ЦД2, із використанням радіонуклідного методу.

\section{Матеріали та методи}

Обстежено 80 чоловіків із ЦД2 віком від 30 до 65 років, які перебували на стаціонарному лікуванні в клініці ДУ «Інститут ендокринології та обміну речовин ім. В.П. Комісаренка НАМН України». Контрольну групу становили 12 осіб відповідного віку без ЦД2. Дослідження виконували на сцинтиляційній томографічній гамма-камері ГКС-301Т (СКТБ «Оризок») із низькоенергетичним коліматором загального призначення. Методом радіонуклідної ангіосцинтиграфії визначали стан кровобігу в нижніх кінцівках, нирках, мозковій тканині та яєчках.

\section{Результати та обговорення}

У чоловіків із ЦД2 за наявності мікро-, макроангіопатій нижніх кінцівок спостерігається сповільнення швидкості повного артеріального кровобігу в стопах за рахунок кровобігу в артеріолах і капілярах без істотних змін інших показників ангіограми. Відсутність порушень часу швидкого кровобігу вказує на задовільну прохідність магістральних судин. Це підтверджується даними літератури, що мікроангіопатія передує розвитку макроангіопатії, нейропатії. Вона поглиблюється з прогресуванням ЦД2 [6, 7].

Аналіз показників ниркової гемодинаміки дозволив виявити суттєве збільшення часу кровобігу в капілярах нирок $(5,82 \pm 0,31$ с у хворих на ЦД2 проти $3,79 \pm 0,23$ с у контрольній групі, p<0,05). Решта досліджених показників не відрізнялися вірогідно від аналогічних контрольної групи. Отримані дані свідчать про уповільнення кровобігу в капілярах у хворих на Цд2 чоловіків на ранніх стадіях нефропатії. Можна констатувати, що мікроангіопатія розвивається перед клінічними проявами нефропатії та передує розвитку макроангіопатії [8].

Результати ангіосцинтиграфії яєчок у чоловіків із ЦД2 засвідчили, що підйом та спад агіографічної кривої були більш пологими, а в деяких хворих упродовж 1-ї хвилини спостереження не було виведення радіофармпрепарату (РФП). В обстежених спостерігали однотипні зміни в обох яєчках у вигляді сповільнення кровобігу в судинах великого та середнього калібру (за показником часу швидкого кровобігу - ЧШК), дрібного калібру (за показником часу повільного кровобігу - ЧПК), а також збільшення часу повного яєчкового кровобігу (ЧПЯК) (табл. 1).

Проведені дослідження підтвердили наявність мікро- і макроангіопатій яєчок у хворих на ЦД2 чоловіків зі статевими розладами. Зважаючи на те, що зменшення швидкості кровобігу в органі може призвести до гіпоксії тканини, можна передбачити певну роль ангіопатій у розвитку структурно-функціональних змін яєчок і в подальшому - у патогенезі статевих розладів. Сповільнення кровопостачання в статевих залозах чоловіків негативно впливає на статеву спроможність [9].

Найбільш виражені зміни мікроциркуляції в обстежених пацієнтів спостерігали за тривалості ЦД2 понад 10 років. Натомість вірогідного кореляційного зв'язку між тривалістю

таблиця 1. Показники яєчкового кровобігу в чоловіків із цукровим діабетом 2-го типу та статевими розладами за даними радіонуклідної ангіограми $(\mathrm{M} \pm \mathrm{m})$

\begin{tabular}{lllllll}
\hline Група & \multicolumn{1}{l}{ чпяК } & \multicolumn{3}{c}{ чшК } & \multicolumn{3}{c}{ чПК } \\
\cline { 2 - 7 } & ля & пя & ля & пя & ля & пя \\
\hline Контроль, & $7,00 \pm$ & $7,14 \pm$ & $4,35 \pm$ & $4,35 \pm$ & $2,65 \pm$ & $2,84 \pm$ \\
с (n=12) & 0,51 & 0,34 & 0,46 & 0,43 & 0,71 & 0,46 \\
ЦД2, & $12,11 \pm$ & $11,41 \pm$ & $6,24 \pm$ & $6,01 \pm$ & $5,78 \pm$ & $5,40 \pm$ \\
С (n=33) & 0,98 & 1,40 & 0,54 & 0,55 & 0,58 & 0,78 \\
p & $<0,001$ & $<0,002$ & $<0,02$ & 0,05 & $<0,002$ & $<0,01$ \\
\hline
\end{tabular}

Примітка: $p$ - вірогідність різничі з контролем; ля - ліве яєчко; ПЯ - праве яєчко. 
захворювання та показниками кровобігу не встановлено. Можливими причинами виявлених змін показників кровобігу можуть бути тяжкість і декомпенсація ЦД.

Серед багатьох чинників порушення кровообігу у хворих на ЦД2 порушення глікемії (гіпер- або гіпоглікемія) посідають одне з провідних місць. Доведено, що більшість серцевосудинних чинників ризику, таких як окислення ліпідів низької щільності, збільшення вмісту тригліцеридів, чинника VII та ендотеліальна дисфункція, є значно більше вираженими на тлі ЦД $[10,11]$ і безпосередньо залежать від різкого збільшення глікемії. Вважають, що оксидативний стрес є одним з основних патофізіологічних ланцюгів між серцево-судинними захворюваннями та діабетом [12].

В обстежених із ЦД2 виявлено вірогідне збільшення часу мозкового кровобігу та часу капілярного кровобігу, що вказує на уповільнення швидкості мозкового кровобігу переважно за рахунок порушення функціонального стану судин системи мікроциркуляції. Збільшення показника виведення радіонукліда може бути зумовлено як уповільненням відтоку крові, так і порушенням проникності судинної стінки. Середні показники часу кровобігу в судинах великого та середнього калібру та інтенсивності кровобігу не змінювались.

3 метою визначення впливу артеріального тиску (АТ) на показники кровобігу, що є надто важливим для мозкового кровообігу, хворих розділили на дві групи. До першої групи увійшли обстежені з нормальним АТ, до другої групи - пацієнти, в яких АТ перевищував $140 / 85$ мм рт. ст.

У хворих на ЦД2 із нормальним АТ порівняно з даними контрольної групи вірогідно збільшувалися показники часу мозкового кровобігу (ЧМК) і часу капілярного кровобігу (ЧКК), показник виведення радіонукліда (ПВР), і зменшувався показник інтенсивності кровобігу (ПІК) (табл. 2). Відомо, що порушення відтоку крові призводить до підвищення венозного тиску. Отже, у хворих із нормальним АТ уповільнення мозкового кровобігу може бути зумовлено передусім порушенням відтоку крові. У хворих із підвищеним АТ порівняно з даними контрольної групи збільшувався лише показник ЧКК.

Звертає на себе увагу той факт, що показник ПІК, який дозволяє виявити порушення деяких механізмів регуляції мозкового кровобігу, змінювався не односпрямовано у хворих із нормальним і підвищеним АТ.

У чоловіків із ЦД2 і нормальним АТ зміни в кровопостачанні виникали частіше за рахунок порушення функціонального стану дрібних артерій і вен. Водночас наявність артеріальної гіпертензії на тлі ЦД2 є однією з провідних причин змін мозкового кровообігу за рахунок порушення механізмів авторегуляції тонусу судин.

Кореляційний аналіз зв'язку між АТ і показниками мозкового кровобігу показав, що збільшення АТ у чоловіків із ЦД2 супроводжується збільшенням інтенсивності крово-

таблиця 2. Показники мозкового кровобігу в чоловіків із цукровим діабетом 2-го типу залежно від рівня артеріального тиску $(\mathrm{M} \pm \mathrm{m})$

\begin{tabular}{|c|c|c|c|c|c|c|c|c|c|c|}
\hline \multirow[t]{3}{*}{ Група } & \multirow{2}{*}{\multicolumn{2}{|c|}{$\begin{array}{l}\text { чМК } \\
\text { півкуля мозку }\end{array}$}} & \multicolumn{2}{|l|}{ ЧшК } & \multicolumn{2}{|l|}{ ЧКК } & \multicolumn{2}{|l|}{ ПIK } & \multicolumn{2}{|l|}{ ПВР } \\
\hline & & & & & & & & & & \\
\hline & $\Pi$ & л & $\Pi$ & л & $\Pi$ & л & $\Pi$ & л & $\Pi$ & л \\
\hline Контроль, с $(n=12)$ & $6,9 \pm 0,27$ & $7,2 \pm 0,18$ & $5,6 \pm 0,21$ & $5,8 \pm 0,21$ & $1,3 \pm 0,06$ & $1,4 \pm 0,25$ & $12,4 \pm 0,64$ & $11,9 \pm 0,43$ & $37,8 \pm 4,62$ & $39,5 \pm 4,75$ \\
\hline $\begin{array}{l}\text { ЦД2, АТ норм., } \\
\text { с }(n=26)\end{array}$ & $8,5 \pm 0,28$ & $8,9 \pm 0,37$ & $5,6 \pm 0,33$ & $5,7 \pm 0,34$ & $2,9 \pm 0,33$ & $3,2 \pm 0,34$ & $9,6 \pm 0,38$ & $9,3 \pm 0,38$ & $52,3 \pm 4,23$ & $54,7 \pm 3,28$ \\
\hline$p$ & $<0,001$ & $<0,001$ & $>0,5$ & $>0,5$ & $<0,001$ & $<0,001$ & $<0,001$ & $<0,001$ & $<0,02$ & $<0,02$ \\
\hline $\begin{array}{l}\text { ЦД2, АТ підвищ., } \\
\mathrm{c}(\mathrm{n}=21) \\
\mathrm{p} \\
\mathrm{p}_{1}\end{array}$ & $7,7 \pm 0,30$ & $7,3 \pm 0,28$ & $5,1 \pm 0,26$ & $4,8 \pm 0,31$ & $2,7 \pm 0,37$ & $2,5 \pm 0,42$ & $14,4 \pm 0,67$ & $15,1 \pm 0,68$ & $49,8 \pm 6,51$ & $48,1 \pm 6,14$ \\
\hline $\begin{array}{l}p \\
p_{1}\end{array}$ & $\begin{array}{l}>0,05 \\
>0,05\end{array}$ & $\begin{array}{l}>0,5 \\
<0,05\end{array}$ & $\begin{array}{l}>0,5 \\
>0,5\end{array}$ & $\begin{array}{l}>0,05 \\
>0,5\end{array}$ & $\begin{array}{l}<0,001 \\
>0,5\end{array}$ & $\begin{array}{l}<0,05 \\
>0,5\end{array}$ & $\begin{array}{l}>0,5 \\
<0,001\end{array}$ & $\begin{array}{l}>0,05 \\
<0,001\end{array}$ & $\begin{array}{l}>0,5 \\
>0,5\end{array}$ & $\begin{array}{l}>0,5 \\
>0,05\end{array}$ \\
\hline
\end{tabular}

Примітка: $p$ - вірогідність різниці з контролем; $p_{1}$ - вірогідність різниці з групою ЦД2, АТ норм.; $n$ — права; Л -ліва. 
бігу в мозку, що може вказувати на схильність до порушення гематоенцефалічного бар'єру незалежно від початкового АТ [13].

\section{Висновки}

1. На ранніх стадіях нефропатії у хворих на ЦД2 чоловіків уповільнюється кровобіг у капілярах.

2. Проведені дослідження підтвердили наявність мікро- і макроангіопатій яєчок у хворих на ЦД2 чоловіків зі статевими розладами.

3. В обстежених із ЦД2 виявлено вірогідне збільшення часу мозкового кровобігу та часу капілярного кровобігу, що вказує на уповільнення швидкості мозкового кровобігу переважно за рахунок порушення функціонального стану судин системи мікроциркуляції.

4. У хворих на ЦД2 мікроангіопатія передує розвитку макроангіопатії та діагностується радіонуклідними методами ще перед появою клінічної симптоматики.

\section{Список використаної літератури}

1. Тронько МД, Лучицький $Є$ В, Паньків ВI. Ендокринні аспекти метаболічного синдрому: навчальний посібник. Київ - Чернівці. 2005; 185 с. (Tron'ko MD, Luchyts'kyy YEV, Pan'kiv VI. Endocrine aspects of metabolic syndrome: a manual. Kyiv Chernivtsi. 2005; 185 p.).

2. Zheng Y, Ley SH, Hu FB. Global aetiology and epidemiology of type 2 diabetes mellitus and its complications. Nat Rev Endocrinol. $2018 \mathrm{Feb} ; 14(2): 88-98$.

3. Guasch-Ferré M, Hruby A, Toledo E, Clish CB, MartínezGonzález MA, Salas-Salvadó J, Hu FB. Metabolomics in Prediabetes and Diabetes: A Systematic Review and Metaanalysis. Diabetes Care. 2016 May;39(5):833-46.

4. Гогин ЕE. Основные тенденции совершенствования диагностики и возрастающее значение инвазивных методов исследования. Тер. архив. 2003;4:5-7. (Gogin YeYe. The main trends in the improvement of diagnostics and the increasing importance of invasive research methods. Ter. arkhiv. 2003;4:5-7).

5. Ходарева ЕН, Минхин, СЕ, Фчкурин ЗС. Сцинтиграфия почек с каптоприлом в диагностике реноваскулярной гипертонии. Тер. архив. 1992;64(4):33-8. (Khodareva YeN, Minkhin SE, Fchkurin ZS. Renal scintigraphy with captopril in the diagnosis of renovascular hypertension. Ter. arkhiv. 1992;64(4):33-8).

6. Grundy SM. Metabolic syndrome. In: Bonora E, DeFronzo R (eds). Diabetes complications, comorbidities and related disorders. Endocrinology. Springer, Cham. 2018;71-107.

7. Sarafidis PA, Whaley-Connell A, Sowers JR, Bakris GL. Cardiometabolic syndrome and chronic kidney disease: what is the link? J Cardiometab Syndr. 2006 Winter;1(1):58-65.

8. Шестакова МВ, Дедов ИИ, Мухин НА, Шереметьева ОВ Метаболические и гемодинамические аспекты диабетической нефропатии. Пробл. ендокринологии. 1993;39(3);55-7. (Shestakova MV, Dedov II, Mukhin NA, Sheremet'yeva OV.
Metabolic and hemodynamic aspects of diabetic nephropathy Probl. endokrinologii. 1993;39(3);55-7).

9. Montorsi F, Briganti A, Salonia A, Rigatti P, Margonato A, Macchi A, et al. Erectile dysfunction prevalence, time of onset and association with risk factors in 300 consecutive patients with acute chest pain and angiographically documented coronary artery disease. J Eur Urol. 2003;44(3):360-4.

10. Малижев ВО, Анастасій ЛВ, Ларін ОС, Неборачко МВ, Гирявенко ОЯ. Ліпоцитокіни в генезі цукрового діабету 2-го типу Клінічна ендокринологія та ендокринна хірургія. 2005;1(10): 3-25. (Malyzhev VO, Anastasiy LV, Larin OS, Neborachko MV, Hyryavenko OYa. Lipocytokines in the genesis of type 2 diabetes mellitus. Klinichna endokrynolohiya ta endokrynna khirurhiya. 2005;1(10):3-25).

11. Kong AP, Chan NN, Chan JC. The role of adipocytokines and neurohormonal dysregulation in metabolic syndrome. Curr Diabetes Rev. 2006 Nov;2(4):397-407.

12. Визир ВА, Березин АЕ. Аполипопротеины как маркеры кардиоваскулярного риска. Укр. мед. Часопис. 2008;6(68) ХІXII:53-61. (Vizir VA, Berezin AYe. Apolipoproteins as markers of cardiovascular risk. Ukr. med. Chasopis. 2008;6(68) XIXII:53-61).

13. McNeill AM, Rosamond WD, Girman CJ, Golden SH, Schmidt MI, East HE, et al. The metabolic syndrome and 11-year risk of incident cardiovascular disease the atherosclerosis risk communities study. Diabetes Care. 2005 Feb;28(2):385-90.

(Надійшла до редакції 25.02.2019 р.)

\section{Радионуклидная диагностика гемодинамических нарушений у мужчин с сахарным диабетом 2-го типа}

\section{Г.А. Зубкова, В.Е. Лучицкий}

ГУ «Институт эндокринологии и обмена веществ им. В.П. Комиссаренко НАМН Украины»

Резюме. Сердечно-сосудистые заболевания являются наиболее распространенной в мире патологией, приводящей к инвалидизации ранней смерти. С их развитием тесно связан диабет 2-го типа (СД2), распространенность которого в настоящее время имеет признаки пандемии. Ранняя диагностика сосудистых поражений различных органов и систем у мужчин с СД2 дает возможность при условии своевременного и адекватного лечения предупредить или замедлить развитие сердечно-сосудистых событий: инфарктов, инсультов. Цель - исследование состояния тестикулярного, почечного и мозгового кровотока у мужчин, больных СД2, с использованием радионуклидного метода. Материалы и методы. Обследованы 80 мужчин, больных СД2, в возрасте от 30 до 65 лет. Исследования состояния кровотока в нижних конечностях, почках, мозговой ткани и яичках выполняли на сцинтиляционной томографической гаммакамере ГКС-301Т (СКТБ «ОризОн»). Результаты. У обследованных наблюдали однотипные изменения в обоих яичках в виде замедления кровотока в сосудах крупного, среднего и мелкого калибра, а также увеличение времени полного яичкового кровотока. На ранних стадиях нефропатии у больных СД2 мужчин замедляется кровоток в капиллярах. У больных СД2 выявлено достоверное увеличение времени мозгового кровотока. Вы- 
Оригінальні дослідження

вод. У больных СД2 микроангиопатия предшествует развитию макроангиопатий и диагностируется радионуклидными методами еще до появления клинической симптоматики.

Ключевые слова: радионуклидная ангиография, сахарный диабет 2-го типа, кровоток, яички.

\section{Radionuclide diagnostic of hemodynamic disturbances in males with metabolic syndrome and type 2 diabetes mellitus}

\section{G.A. Zubkova, V.Ye. Luchytsky}

State Institution «V.P. Komisarenko Institute of Endocrinology and Metabolism, NAMS of Ukraine»

Abstract. Cardiovascular diseases are the most common pathology in the world, leading to disability of early death. Their development is closely associated with type 2 diabetes mellitus (T2DM), the prevalence of which currently has signs of a pandemic. Early diagnosis of vascular lesions of various organs and systems in men with T2DM makes it possible, under the condition of timely and adequate treatment, to prevent or slow down the development of cardiovascular events: heart attacks, strokes. The goal is to study the state of testicular, renal and cerebral blood flow in men with diabetes mellitus using the radionuclide method. Materials and methods. 80 male patients with T2DM, aged 30 to 65 years, were examined. Investigations of the state of blood flow in the lower extremities, kidneys, brain tissue and testicles were performed on a GCS-301T scintillation tomographic gamma camera (Orizon STTE) Results. In the examined, similar changes in both testicles were observed in the form of slowing blood flow in the vessels of large, medium and small caliber, as well as an increase in the time of complete testicular blood flow. In the early stages of nephropathy in patients with diabetes mellitus, the blood flow to the capillaries slows down. A significant increase in cerebral blood flow time was found in patients with T2DM. Conclusion. In patients with T2DM, microangiopathy precedes the development of macroangiopathies and is diagnosed by radionuclide methods even before the onset of clinical symptoms

Keywords: radionuclide angiography, type 2 diabetes mellitus, blood flow, testes. 